\title{
Skills and Attributes Needed for Success in Accounting Career: Do Employers' Expectations Fit with Students' Perceptions? Evidence from Tunisia
}

\author{
Mohamed Faker Klibi ${ }^{1} \&$ Ahmed Atef Oussii ${ }^{1}$ \\ ${ }^{1}$ Higher School of Economic and Commercial Sciences of Tunis, University of Tunis, Tunisia \\ Correspondence: Ahmed Atef Oussii, Higher School of Economic and Commercial Sciences of Tunis, University \\ of Tunis, 1089 Montfleury Tunis, Tunisia. Tel: 216-53-839-207. E-mail: ahmed_atef.oussii@yahoo.fr
}

Received: January 16, 2013 Accepted: March 2, 2013 Online Published: March 22, 2013

doi:10.5539/ijbm.v8n8p118 URL: http://dx.doi.org/10.5539/ijbm.v8n8p118

\begin{abstract}
Purpose - The aim of this article is to examine perceptions and expectations of two major stakeholders: students and employers of the importance of skills and attributes for securing entry-level employment in accounting.

Design/methodology/approach - The authors conduct an empirical study using a list of 78 items, starting by comparing employers' expectations with students' perceptions concerning the set of technical and non technical skills required from accounting graduates to pursue a career in the accounting profession This study involving data collection from 81 accounting students in five business schools in Tunisia and 48 practitioners.
\end{abstract}

Findings - Findings indicate that employers are seeking graduates who possess a diverse range of non-technical skills. However, accounting students perceive that it is rather technical skills which determine their abilities to pursue a career in the accounting profession.

Practical implications - The paper's findings are of interest to several different parties, primarily the professional accounting body, universities and students.

Originality/value - The paper describes an empirical study, conducted on a developing country, which provides a better understanding of new skills expected for future accountants in this changing business environment. The paper constitutes also a meaningful contribution to the accounting education literature, as it examines an interesting subject that has not yet been investigated in the Tunisian context.

Keywords: accounting education, technical skills, generic skills, Tunisia

\section{Introduction}

The last two decades have been marked by the internationalization of the world economy and the emergence of new information technologies. This phenomenon has triggered a widespread awareness, reflected by the human capital theory, which supposes that employees play an important role and give the company a sustainable competitive advantage. Therefore, human capital constitutes an attractive source of organizational performance. The job of the accountant seems to be at the heart of this logic. Indeed, these change drivers have had major impacts on the quality of the accounting work which lead accountants to develop new skills (Bescos, 2002; Albrecht and Sack, 2000). New global business models have meant the role of the traditional accountant (De Lange, and Guf Jackling, 2006). Traditionally considered as a score-keeper, a bean counter and a corporate cop (Siegel, 2000), the accountant must be now regarded as a professional with a sense of leadership, able to manage a team and to exercise a rigorous and transparent judgement in several situations (Williams, 1994; Bescos, 2002; Howieson, 2003; Jones and Abraham, 2009). As a result, employers / recruiters are seeking a diverse range of skills and attributes in new accounting graduates (Wells et al., 2009; Kavanagh and Drenan, 2008). In this context, Birrell (2006) suggests that the managerial needs to take quick action and to maintain the competitive position, pushed employers to model a new accounting graduate profile with a large range of technical and generic skills. However, it seems that accounting students are generally unaware of the new skills currently expected for future accountants in this highly changeable global business context. Recently, the accounting education worldwide has been the subject of much debate. Several researchers argue that accounting graduates are ill-equipped to begin professional practice (Albin and Crockett, 1991; Van Wayhe, 1994 West, 1998, Hall, 
1998; Albrecht and Sack, 2000; Mathews, 2001, and Mohamed Lashine, 2003). Others suggest that higher education accounting must meet employers' expectations in terms of learning and professional development (Albrecht and Sack, 2000; Chabrow and Hayes, 2001; Forristal, 2002). Hence, the challenge for the accounting education system is to build graduate attributes within and across programmes.

This explains the studies conducted by several researchers to identify accounting education deficiencies and to recommend changes in course emphasis (Albrecht and Sack, 2000; Birkett, 1993; Mathews et al., 1990). Also, accounting programmes are being revised to provide adequate training for future accountants in the United States, Australia, Spain, France, the UK and still in Tunisia. Hassel et al. (2005) argue that these reforms aim to improve the quality of education and to reduce the expectations gap between students' perceptions and employers' expectations.

This study addresses the following research questions:

- What skills do employers expect of accounting graduates at recruitment, in training and in ongoing accounting employment?

- What professional skills do graduating accounting students perceive as having the highest priority for career success?

The objective of this paper is to test this quote in a developing country: Tunisia. This country is located on the Mediterranean coast of North Africa. Since 1995, Tunisia has joined the World Trade Organization and has chosen, therefore, to liberalize its economy and to open it to financial and technology transfers coming particularly from developed countries.

Thus, this new economic environment has led to increase competition between companies and has put pressure on the Tunisian labor market, which obviously failed to follow the needs of the economy. This fact explains the relatively high level of unemployment in the country (18.3\%) (Note 1). Furthermore, the specificity of unemployment in Tunisia is affecting the majority of graduates (30.9\%) (Note 2). Further, the university has been accused of not understanding employer expectations of desirable entry-level operations management skills. To remedy this situation, the public authority in Tunisia has implemented a reform to bring closer the curriculum to employers needs. As consequence, a decree dated July 13, 2005 launched the regime BMD (Bachelor - Master Doctorate) in Tunisia. This system, which was set up to follow the World Bank recommendations' was inspired by the Anglo-Saxon educational system, adopted also by the European Union since the process of Bologna (1999). Moreover, the particularity of this device is that it provides a "Bachelor degree", which continues for a period of three years after the high school diploma, designed to meet the needs of labor market. The training of future accountants in Tunisia is in most cases, under these licenses applied.

We assume in this paper that skills expected for future accountants constitute a standard that should guide the educational behaviour of students who choose to follow accounting program. Thus, employers' expectations may shape the accounting student motivation and implementation of a rigorous strategy that facilitate the acquisition of skills and attributes (through internships) from his passage by the university. This logic is consistent with career development theories that attempt to explain students' perceptions. According to these theories, individuals can influence their career progress by adopting behavioural strategies and by developing the relational dimension and skills deemed important by employers, in order to facilitate their career success. Herewith, this paper is organized as follows: the second section will focus on the literature review. The third section is devoted to the formulation of hypotheses. The fourth describes the methodology. Results and interpretations will be presented in the fifth section.

\section{Literature Review}

The portfolio of an accounting graduate skills is composed of multiple knowledge and skills acquired throughout the university curriculum and consolidated by the practice. Indeed, technical skills enable the professional accountant to conduct his work effectively and to satisfy his employer or client. According to IES 3 "professional skills"(Note 3), technical and functional skills consist of general skills as well as skills specific to accountancy. They include: (a) numeracy (mathematical and statistical applications) and IT proficiency; (b) decision modeling and risk analysis; (c) measurement; (d) reporting; and (e) compliance with legislative and regulatory requirements.

Furthermore, the expansion of the skills base in higher education accounting programs has been suggested as a way to provide accountants more flexibility and adaptability given the continuous evolution of the labor market (Chaker and Abdullah, 2012, Daff et al., 2012). Many studies suggest that the gap between education and practice is widening requiring curriculum change (Bowden and Masters, 1993; Albrecht and Sack, 2000). In fact, 
competitive pressures and technology evolution have led to expectations that accounting graduates prove additional skills to suit to new challenges (Bowden et al., 2000). Besides technical capacities, business appears to expect more and more generic skills such as personal qualities, interpersonal and intellectual. These attributes "are more related to personality and can be worth in various functions. (i.e. leadership, initiative)" (Note 4). These requirements have influenced, since the 1990's, the professional bodies in developed countries which, in turn, proposed to include these skills in the accounting higher education programs (Jackling and De Lange, 2009). Previous studies often show that these skills have not the same weight in the labor market of accountants. In fact, technical competencies are still regarded as implicit in the skills set of an entry-level graduate. De Lange et al. (2006) suggest that it is 'personal characteristics' that enable career success. As for the employers, it seems that they agree that generic skills are more added-value to the company. To explain this finding, Hunton (2002) indicates that many traditional accounting tasks have become automated, which allows to claim that the value of professional accountant is now in generic skills. Even more, it has been shown that employers consider the technical capabilities, directly related to the accounting profession, as implicit and obvious.

In other terms, they assume their availability in the skill set required for a career in as an accountant (Albrecht and Sack, 2000). In the same vein, studies conducted by Birkett (1993), ICAEW (1996) and the AICPA (1999) and sponsored by accounting standard setters in Australia, United Kingdom and even the United States have identified capabilities and skills desired by professional accountants/recruiters. In fact, results show that beyond the technical functional skills, professional accountants require general business skills and personal skills (such as communication, leadership, creative and critical thinking) and interpersonal skills (i.e. the ability to adapt to change and work in different contexts). These skills are very important because they "enable the professional accountant to make successful use of the knowledge gained through education" (IFAC, 1996, p.16). Based on our review of the literature, it appears that employers are interested in motivated graduates (Kim et al, 1993) who are able to solve real problems (Novin and Pearson, 1989; ACNielsen Research Sevices, 2000, Hunton, 2002; Burnett, 2003; Lashin and Mohamed, 2003; DiGabriele, 2008) and with a large capacity of communication and analysis, (Morgan, 1997; Gammie et al., 2001, Hunton, 2002; Lashine and Mohamed, 2003; Burnett, 2003; DiGabriele, 2008).

In addition, other generic skills could be considered by employers as key criteria in the recruitment of new accounting graduates, such as oral, written communication, listening skills (Novin and Pearson, 1989; Kim et al., 1993, Simons et al. 1995; Blaszczynski, 1999 ACNielsen Research Sevices, 2000, Hassall et al., 2005 and Borzi and Mills, 2001) and teamwork (Blaszczynski, 1999; ACNielsen Research Sevices, 2000; Borzi and Mills, 2001; Hassal and al., 2005). Moreover, it seems that these criteria are often desired. In fact, employers / recruiters believe that new graduates are ill-equipped in terms of leadership and skills related to communication and teamwork (Jackling and De Lange, 2009). Besides, previous researches have attempted to examine accounting students' perceptions' concerning skills needed to make a successful career. Although, several studies found that students ranked technical as the most important to ensure career success (Daly and McCroskey, 1975 Rebel, 1985; Usoff and Feldman, 1998, Hunt et al., 2004; Jones and Abraham, 2008; Ameen et al., 2010). This result does not seem to be counter-intuitive, since the subjects taught in business schools (accounting, finance, business law,..) are often transmitting technical skills and attributes.

Even more, it was often found that teachers do not consider generic skills as important for accounting practice (Hunt et al., 2004, Wells et al., 2009). It follows that emphasis placed by universities on technical skills is more pronounced. This fact led to another phenomenon, which is not less harmful to the accounting profession: students who choose accounting as major are no longer the best (Albrecht and Sack, 2000). We believe that this observation is still true in the Tunisian context. In fact, the Tunisian university is known for its isolation from the professional environment. Moreover, unlike universities in developed countries (belonging to the OECD), in the Tunisian business schools, there is no relay (career center, job fairs or alumni associations) that allow students to anticipate the real needs of recruiters in the accounting field, especially in term of generic skills. On the other hand, Accounting standard setting bodies do not attempt to exercise pressure on the Tunisian schools of business in raising awareness about the importance of such skills (Note 5). According to our assumptions, a gap may exist between employer expectations of employment skills and attributes, and student perceptions of those expectations (Francisco and Kelly 2002, Lin et al., 2005; Bui and Porter, 2008). This gap is -it justified? Gati (1998) and Arquero et al., (2001) suggest that employers may prioritize capabilities that are that are not developed in most accounting programs. As consequence, the mis-match between entry level graduates and the requirements of organizational environments is likely to see opportunities for new graduates become increasingly limited (Kavanagh et al., 2009). This view is supported by Leveson (2000) who states that the absence of a common vocabulary between education and professional environment widens the gap between 
students' perceptions and employers' expectations.

\section{Formulation of Hypotheses}

From the above review of extant literature, it is clear that an expected marketable skill base gap existed between the expectations of employers and those of students. The following research hypotheses are addressed:

1) Employers will perceive that generic skills are more important than technical skills for obtaining an entry-level position.

2) Students will perceive that technical skills are more important than generic skills to begin professional practice.

3) There will be differences between employers and students in their perceptions of the importance of technical skills, and generic attributes.

\section{Research Methodology}

\subsection{Sample}

We conducted a study involving data collection from 92 graduating students in five schools of business in Tunisia and 82 practitioners across a number of organizations and audit firms which employ accounting graduates. A total of 81 usable responses were received from accounting students, giving a response rate of $91 \%$ (see Table 1). The final sample of practitioners comprised 48 professionals accountants (see Table 2), with a response rate of $58.53 \%$. This level of response is typically seen as acceptable when using a survey method (Zikmund, 2000).

Table 1. Demographics of student respondents

\begin{tabular}{lcccc}
\hline Gender & \multicolumn{4}{c}{ Age groups } \\
\hline Men & $19-23$ & $24-26$ & $27-30$ & Over 30 \\
Women & 25 & 4 & 0 & 0 \\
Total & 44 & 7 & 1 & 0 \\
\hline
\end{tabular}

Table 2. Demographics of employer respondents

\begin{tabular}{lccc}
\hline Experience & Total Number of Respondents & Certified Public Acountants & Charted Accountants \\
\hline Less than 5 years & 16 & 11 & 5 \\
Between 5 et 10 years & 19 & 15 & 4 \\
More then 10 years & 13 & 4 & 9 \\
Total & 48 & 30 & 18 \\
\hline
\end{tabular}

\subsection{Measurement of Variables}

The quantitative study involved the same survey being administered to accounting students (studying last level in Bachelor of Accounting) and practitioners certified public accountants (Note 7) and Chartered Accountants (Note 8)). In fact, the respondents were asked to nominate the skills that they deemed to be most important for job success in accounting. These questionnaires were administered during the period from March 2011 to June of the same year. The survey instrument was pilot-tested on a small group of students and practitioners to assess the instrument's face validity and clear up any ambiguity and wording issues.

The individual items for generic and technical skills and attributes were based on the literature (Albrecht and Sack, 2000; Gabric and McFadden, 2001; De Lange et al., 2006; Kavanagh et Drenan, 2008; Kerlan, 2000; Yaich, 2005; Goleman, 1999; Mathews et al., 1990) as well as on the Accounting Course Requirements in Tunisia. Minor refinements were made for the Tunisian context and to include points recommended by students and professionals through the qualitative phase (Note 6) which allows us to compile a list consisting of 78 items divided into seven categories: (1) Technical skills (accounting, financial and tax), (2) management skills, (3) IT skills,(4) Physical qualities, (5) Intellectual skills, (6) Interpersonal skills and (7) Personal skills. Thus, respondents were asked to rate 78 skills/attributes on a scale ranging from 1 (no priority) to 5 (top priority). All used items can be viewed by referring to Tables 2 and 4 which show together the results of the study. Data from 
the questionnaires were analysed using spss version 18 for Windows.

\subsection{Statistical Analysis Method}

Among employers and students, we computed an overall mean total score for each factor. We assessed the internal consistency of the sets of questions within each factor using Cronbach's alpha (Cronbach, 1951; Hosmane et al., 2000). As seen in Table 3, the values of Cronbach's alpha ranged from 0.7 to 0.912 , indicating strong internal consistency among items within each factor. To measure the dispersion of responses, we calculated the standard deviation and the coefficient of variation (CV). This coefficient (standard deviation / mean) would assess the level of consensus among the sample. According to Lapointe (1995, p.256), the consensus of respondents is: excellent if $\mathrm{CV}<15$, good if $15<\mathrm{CV}<30$ and low if $\mathrm{CV}>30$. To determine whether employers (and students) valued generic skills significantly more than technical skills (Hypothesis 2 and 3 ), we compared the overall mean scores of personal, interpersonal and intellectual skills to the overall mean scores of technical skills using a one-tailed paired t-test.

In addition to hypothesis testing, rankings were developed that summarize the relative importance to employers of various generic skills, personality characteristics and technical skills. Similarly, rankings were produced on student perceptions of the importance of these skills and attributes.

\section{Results}

Our first research hypothesis was whether generic skills were more important than technical skills among employers. Results show (Table 3 and 4) that the overall mean score for various generic skills was higher than the overall mean score for technical abilities. To address hypothesis 2 , whether students believed technical skills were more important than soft (generic) skills. We found that the students' overall mean score for technical skills was significantly higher than the mean score for generic abilities.

Our third research hypothesis was whether the overall scores for general business skills, technical skills, and personality characteristics would differ for employers and students. The t-test indicates that all three factors were different for employers and students. Table 4 provides the mean scores for each factor.

\subsection{Employer Perceptions}

\section{Important skills for an entry-level position:}

Table 3 lists the skills set in the order of importance among employers. Analysis shows that Tunisian professionals have reported that interpersonal, personal and intellectual skills, physical qualities and IT skills were ranked as the top three skills valued by employers. Furthermore, it should be noted that all proposed items received mean scores above 3 excepting the item "Advertising and promotion." This means that professionals surveyed agree that these skills are of importance greater than the mean-score. In addition, 40 of the 78 items were offered an average score above 4 (High importance). Analytically, the following skills were ranked at the bottom of the list: (1) The ability to inspire confidence (Credibility, honesty and openness), (2) ethical awarness, (3) Capacity for dialogue, exchange and negotiation, (4) the desire for personal success (5) The ability to work on team. In fact, these skills received mean scores above 4 with a good level of consensus on the part of respondents $(\mathrm{CV}<30)$. These skills were considered to have at least a high importance to employers. Even if we extend the scope of our results, findings show that personal skills (personal and moral autonomy, dynamism), interpersonal skills (teamwork, communication, leadership), intellectual skills (critical thinking, the time management and pressure) and IT skills (the selection and the use of appropriate software) have been highly classified by all practitioners.

In short, it appears that accounting professionals are seeking a diverse set of generic traits (non technical) in new accounting graduates, because may be, these skills are crucial in creating added value. These results are similar to the findings of several previous researches (Zaid and Abraham, 1994; Johnson and Johnson, 1995; Morgan, 1997; Lee and Blaszczynski, 1999; Baker and McGregor, 2000, Abraham and Jones, 2008) who found that generic skills (especially, ethical awareness and communication) are real keys success factors. The employers also ranked technical abilities as less important than soft skills. Therefore, we can say that professional accountants consider these skills as implicit; their presence in the skills base of accounting graduates is quite obvious. This finding corroborates the results of researches conducted in other contexts such as the United States (Gabric and MacFadden, 2001) and Australia (De Lange et al., 2006; Kavanagh and Drenan, 2008; Kavanagh et al., 2009). To better summarize the items and to reduce the complexity of our analysis, further data analysis was conducted. So, we treated the results for skills grouped by category by calculating an overall mean score for each skills factor. We, also, calculated the Cronbach's alpha coefficient to ensure the internal consistency of our advanced skills factors. 
Table 3. Important skills for an entry-level position: employers ranking

\begin{tabular}{|c|c|c|c|c|c|}
\hline \multicolumn{2}{|c|}{ Rank Catego-ries* } & \multirow{2}{*}{$\begin{array}{l}\text { Items } \\
\text { The ability to inspire confidence (credibility, honesty) }\end{array}$} & \multirow{2}{*}{$\begin{array}{r}\begin{array}{l}\text { Mean } \\
\text { score }\end{array} \\
4,75\end{array}$} & \multirow{2}{*}{$\begin{array}{c}\begin{array}{c}\text { Standard } \\
\text { deviation }\end{array} \\
0,478\end{array}$} & \multirow{2}{*}{$\begin{array}{c}\begin{array}{c}\text { coefficient } \\
\text { of variation }\end{array} \\
10,06\end{array}$} \\
\hline 1 & VI & & & & \\
\hline 2 & VII & Ethical awreness & 4,61 & 0,637 & 13,81 \\
\hline 3 & VI & Capacity for dialogue, exchange and negotiation & 4,54 & 0,536 & 11,80 \\
\hline 4 & VII & Desire for personal success & 4,50 & 0,707 & 15,71 \\
\hline 5 & VI & Collaborate with other teams & 4,437 & 0,609 & 13,72 \\
\hline 6 & $\mathrm{~V}$ & Organize workload and handle tight deadlines & 4,416 & 0,786 & 17,79 \\
\hline 7 & VII & Continuous learning & 4,35 & 0,806 & 18,54 \\
\hline 8 & III & The selection and the use of appropriate software & 4,33 & 0,874 & 20,18 \\
\hline 9 & VII & Self confidence & 4,31 & 0,711 & 16,49 \\
\hline 10 & VI & $\begin{array}{l}\text { Present and to defend points of view and the outcomes } \\
\text { of their own work, verbally, to colleagues, clients, and } \\
\text { superiors }\end{array}$ & 4,27 & 0,604 & 14,14 \\
\hline 11 & $\mathrm{~V}$ & Critical analysis & 4,26 & 0,756 & 17,74 \\
\hline 12 & V & Solve unstructured problems & 4,26 & 0,433 & 10,16 \\
\hline 13 & VI & $\begin{array}{l}\text { Present and defend points of view and the outcomes of } \\
\text { their own work, in writing, to clients, and superiors }\end{array}$ & 4,25 & 0,478 & 11,24 \\
\hline 14 & III & Hardware skills & 4,24 & 0,66 & 15,56 \\
\hline 15 & V & Select and assign work priorities & 4,23 & 0,895 & 21,16 \\
\hline 16 & VI & Listen effectively to obtain information & 4,23 & 0,62 & 14,65 \\
\hline 17 & VII & Social adaptability & 4,22 & 0,696 & 16,49 \\
\hline 18 & V & Analysis capacity and logical thinking & 4,20 & 0,796 & 18,97 \\
\hline 19 & VII & Pressure resistance & 4,21 & 0,61 & 14,51 \\
\hline 20 & $\mathrm{~V}$ & Critical reading & 4,187 & 0,526 & 12,56 \\
\hline 21 & IV & Good posture and looking presentable & 4,18 & 0,44 & 10,52 \\
\hline 22 & IV & Personal style & 4,166 & 0,656 & 15,74 \\
\hline 23 & VII & Tenacity, perseverance and self-motivation & 4,16 & 0,687 & 16,51 \\
\hline 24 & VII & Listening skills & 4,187 & 0,696 & 16,62 \\
\hline 25 & IV & Personal health practices & 4,125 & 0,696 & 16,87 \\
\hline 26 & VI & Leadership & 4,125 & 0,525 & 12,72 \\
\hline 27 & I & Conduct audits and prepare final reports & 4,125 & 0,753 & 18,25 \\
\hline 28 & II & Organize and manage human resources & 4,105 & 0,742 & 18,07 \\
\hline 29 & VI & Mastering foreign languages & 4,104 & 0,620 & 15,10 \\
\hline 30 & III & Computer Security skill & 4,104 & 0,871 & 21,29 \\
\hline 31 & VI & Organize and delegate work & 4,104 & 0,742 & 18,07 \\
\hline 32 & VII & Sense of personal identity & 4,083 & 0,786 & 19,25 \\
\hline 33 & VII & Take reasonable job work risk & 4,084 & 0,533 & 13,05 \\
\hline 34 & I & Prepare financial statements & 4,083 & 0,671 & 16,43 \\
\hline 35 & VII & Sense of humor & 4,062 & 0,316 & 7,778 \\
\hline 36 & VI & Ability to facilitate & 4 & 0,583 & 14,57 \\
\hline 37 & VII & Flexibility & 4,041 & 0,705 & 17,44 \\
\hline 38 & VI & sense of solidarity & 4,041 & 0,842 & 20,83 \\
\hline 39 & $\mathrm{~V}$ & Find effective ways to solve problems & 3,97 & 0,802 & 20,20 \\
\hline
\end{tabular}




\begin{tabular}{|c|c|c|c|c|c|}
\hline 40 & VII & Adapt to situation of change & 4 & 0,735 & 18,37 \\
\hline 41 & III & Use and understand various information & 3,98 & 0,875 & 21,98 \\
\hline 42 & I & Analyze cost and margins & 3,98 & 0,875 & 21,98 \\
\hline 43 & VII & Personal convictions & 3,95 & 0,45 & 11,39 \\
\hline 44 & VII & optimism & 3,95 & 0,454 & 11,49 \\
\hline 45 & VII & Emotional Stability: self-control, calm, good humor & 3,937 & 0,689 & 17,49 \\
\hline 46 & I & Conduct inventory and check accounting records & 3,937 & 0,876 & 22,24 \\
\hline 47 & I & Prepare tax returns & 3,91 & 0,812 & 20,76 \\
\hline 48 & $\mathrm{~V}$ & The ability to obtain various information & 3,90 & 0,796 & 20,41 \\
\hline 49 & I & Track inventory analysis & 3,89 & 1,020 & 26,22 \\
\hline 50 & $\mathrm{~V}$ & Find creative solutions & 3,87 & 0,865 & 22,35 \\
\hline 51 & I & Technical/bookkeeping (accounts receivable/payable) & 3,875 & 0,726 & 18,73 \\
\hline 52 & I & Ensure effective financial control & 3,875 & 0,832 & 21,47 \\
\hline 53 & I & Ensure the smooth running of internal control & 3,85 & 1,117 & 29,01 \\
\hline 54 & I & Mastering tax system & 3,83 & 0,687 & 17,93 \\
\hline 55 & I & Consolidate financial statements & 3,80 & 1,104 & 29,05 \\
\hline 56 & I & Accounting for property, plant, and equipment. & 3,78 & 0,934 & 24,70 \\
\hline 57 & VI & The Use of visual aids in presentations & 3,76 & 0,899 & 23,90 \\
\hline 58 & III & Perform electronic transfer of accounting data & 3,75 & 0,803 & 21,41 \\
\hline 59 & I & Perform the bank reconciliation statement & 3,704 & 0,575 & 15,52 \\
\hline 60 & II & Mastering Good Governance series & 3,687 & 0,845 & 22,91 \\
\hline 61 & I & To record provisions for depreciations & 3,66 & 0,563 & 15,38 \\
\hline 62 & III & Ability to develop effective learning methods & 3,65 & 0,920 & 25,20 \\
\hline 63 & I & Prepare payroll & 3,64 & 0,628 & 17,25 \\
\hline 64 & II & Participate in planning & 3,625 & 0,60 & 16,55 \\
\hline 65 & III & Describe and use a procedure for data interchange & 3,60 & 0,929 & 25,80 \\
\hline 66 & VII & Empathy & 3,57 & 0,671 & 18,79 \\
\hline 67 & II & Actuarial and risk assessment & 3,54 & 1,274 & 36,00 \\
\hline 68 & I & Cash management Basics & 3,5 & 0,865 & 24,71 \\
\hline 69 & I & Strategic management & 3,48 & 1,080 & 31,03 \\
\hline 70 & I & Analyze business performance & 3,46 & 1,116 & 32,25 \\
\hline 71 & II & The use of quantitative methods and statistics & 3,33 & 0,877 & 26,33 \\
\hline 72 & I & Prepare invoices control & 3,312 & 0,960 & 28,98 \\
\hline 73 & I & Update control procedures & 3,30 & 1,140 & 34,54 \\
\hline 74 & IV & Practice Sports & 3,22 & 1,240 & 38,50 \\
\hline 75 & I & Develop and manage budgets & 3,208 & 0,762 & 23,75 \\
\hline 76 & II & Develop business plans & 3,17 & 0,897 & 28,31 \\
\hline 77 & II & Investment Analysis and Portfolio Management & 3 & 0,957 & 31,9 \\
\hline 78 & II & Advertising and promotion & 2,70 & 1,159 & 42,92 \\
\hline
\end{tabular}

Note: (I) Technical skills (accounting, financial and tax), (II) Management skills, (III) Information Technology Skills, (IV) Physical qualities, (V) Intellectual skills, (VI) Interpersonal skills and (VII) personal skills.

Analysis of overall average scores for the various skill categories (see Table 3) shows that they have received scores important and close in terms of value. Thus, we can say that professional accountants agree on the importance of these skills for an entry-level position. However, we note that generic skills factors dominate technical skills categories. In fact, the overall mean score for generic skills (Intellectual, interpersonal and 
personal) exceed 4. However, the overall mean score for technical abilities is equal to 3.71 .

Table 4. Inter-category analysis: employers' rankings

\begin{tabular}{clcc}
\hline Categories & Skill categories & Mean score & Cronbach's alpha \\
\hline I & Technical skills & 3,71 & 0,866 \\
II & Management skills & 3,315 & 0,822 \\
III & Information Technology Skills & 3,916 & 0,808 \\
IV & Physical qualities & 3,921 & 0,70 \\
V & Intellectual skills & $\mathbf{4 , 1 4 1}$ & 0,739 \\
VI & Interpersonal skills & $\mathbf{4 , 1 1}$ & 0,739 \\
VII & Personal skills & $\mathbf{4 , 1 3 6}$ & 0,912 \\
\hline
\end{tabular}

\subsection{Student Perceptions}

Important general skills for an entry-level position:

Table 4 provides a ranking of general skills in order of importance among students. According to students, all the listed skills are important for an entry-level position. In fact, 32 skills received a score higher than 4 . In addition, 44 of the 78 skills were featured in a good place and have thus received scores between 3 and 4 with a good level of consensus on the part of respondents. In fact, these skills were considered to have at least moderate importance. It should be noted that technical knowledge were considered by students surveyed, at least, as important for a successful career. Moreover, 13 technical skills received a mean score greater than 4 .

Moreover, students ranked: (1) Prepare financial statements with a score equal to 4.59, (2) Technical bookkeeping (accounts receivable/payable) with a mean score of 4.506, (3) Accounting for depreciation and provisions with a mean score of 4.395 , as the top three skills necessary for obtaining a position after graduation. On the other hand, updating the control procedures and analyzing business performance were ranked by students at the bottom of the list with a high level of consensus (CV 29.58 and 25.6 respectively). These scores could be explained by the fact that students tend to favor fields related to financial reporting. Along with employers, students ranked highly several soft skills such as (1) the ability to dialogue, exchange and negotiation, (2) the desire for personal success, (3) the ability to inspire trust, credibility and openness.

Table 5. Technical \& generic skills: students' ranking

\begin{tabular}{lllccc}
\hline Rank & Categories & Items & $\begin{array}{c}\text { Mean } \\
\text { score }\end{array}$ & $\begin{array}{l}\text { Standard } \\
\text { deviation }\end{array}$ & $\begin{array}{l}\text { coefficient } \\
\text { of variation }\end{array}$ \\
\hline 1 & I & Prepare financial statements & $\mathbf{4 , 5 9}$ & 0,787 & 17,14 \\
2 & I & Technical bookkeeping (accounts receivable/payable) & $\mathbf{4 , 5 0 6}$ & 0,572 & 12,69 \\
3 & I & To record provisions for depreciations & $\mathbf{4 , 3 9 5}$ & 0,664 & 15,10 \\
4 & I & Cash management basics & $\mathbf{4 , 3 5 8}$ & 0,841 & 19,29 \\
5 & VI & Ability to inspire confidence (credibility, honesty) & $\mathbf{4 , 3 4 5}$ & 0,896 & 20,62 \\
6 & VI & Capacity for dialogue, exchange and negotiation & $\mathbf{4 , 3 3 3}$ & 0,866 & 19,98 \\
7 & VII & The desire for personal success & $\mathbf{4 , 3 0 8}$ & 0,869 & 20,17 \\
8 & I & Conduct audits and prepare final reports & $\mathbf{4 , 2 8 3}$ & 0,951 & 22,20 \\
9 & VI & Listen effectively to obtain information & $\mathbf{4 , 2 5 9}$ & 0,787 & 18,47 \\
10 & I & Ensure effective financial control & $\mathbf{4 , 2 3 4}$ & 0,855 & 20,19 \\
11 & III & Use and understand various information & 4,225 & 0,940 & 22,24 \\
12 & I & Consolidate financial statements & 4,222 & 0,821 & 19,44 \\
13 & I & Prepare tax returns & 4,222 & 0,880 & 20,84 \\
14 & III & The selection and the use of appropriate software & 4,209 & 0,958 & 22,76 \\
\hline
\end{tabular}




\begin{tabular}{|c|c|c|c|c|c|}
\hline 15 & I & Perform the bank reconciliation statement & 4,209 & 0,832 & 19,76 \\
\hline 16 & $\mathrm{~V}$ & Organize workload and handle tight deadlines & 4,197 & 0,842 & 20,06 \\
\hline 17 & I & Mastering tax system & 4,160 & 0,813 & 19,54 \\
\hline 18 & I & Accounting for property, plant and equipment & 4,135 & 0,841 & 20,33 \\
\hline 19 & VII & Tenacity, perseverance and self-motivation & 4,135 & 0,858 & 20,74 \\
\hline 20 & I & Prepare invoices control & 4,123 & 0,832 & 20,17 \\
\hline 21 & VI & $\begin{array}{l}\text { Present and defend points of view and the outcomes of } \\
\text { their own work, verbally, to colleagues, clients, and } \\
\text { superiors }\end{array}$ & 4,112 & 0,885 & 21,52 \\
\hline 22 & III & Hardware skills & 4,111 & 0,948 & 23,06 \\
\hline 22 & $\mathrm{~V}$ & Select and assign work priorities & 4,111 & 0,866 & 21,06 \\
\hline 24 & VI & Listening skills & 4,11 & 0,86 & 20,92 \\
\hline 24 & VII & Self confidence & 4,11 & 0,846 & 20,58 \\
\hline 26 & VII & Flexibility & 4,098 & 0,87 & 21,22 \\
\hline 26 & $\mathrm{I}$ & Conduct inventory and check accounting records & 4,098 & 0,874 & 21,32 \\
\hline 28 & VI & Mastering foreign languages & 4,05 & 0,926 & 22,86 \\
\hline 29 & VI & Collaborate with other teams & 4,049 & 0,864 & 21,33 \\
\hline 29 & VII & Take reasonable job related risk & 4,049 & 0,80 & 19,75 \\
\hline 31 & IV & Good posture and looking physically presentable & 4,024 & 0,865 & 21,49 \\
\hline 32 & IV & Personal style & 4 & 0,961 & 24,02 \\
\hline 33 & VII & Personal convictions & 4 & 0,8012 & 20,03 \\
\hline 34 & $\mathrm{~V}$ & Find creative solutions & 3,987 & 0,968 & 24,27 \\
\hline 35 & VI & Sense of solidarity & 3,962 & 0,908 & 22,91 \\
\hline 36 & IV & Personal health practices & 3,950 & 0,850 & 21,51 \\
\hline 36 & I & Ensure the smooth running of internal control & 3,950 & 0,893 & 22,60 \\
\hline 36 & VI & Organize and delegate works & 3,950 & 0,920 & 23,29 \\
\hline 39 & $\mathrm{~V}$ & Critical thinking & 3,938 & 0,907 & 23,03 \\
\hline 40 & VII & Emotional Stability: self-control, calm. & 3,925 & 0,899 & 22,9 \\
\hline 40 & VII & Self-training & 3,925 & 0,749 & 19,08 \\
\hline 42 & I & Analyze cost and margins & 3,913 & 0,911 & 23,28 \\
\hline 42 & I & Develop and manage budgets & 3,913 & 0,977 & 24,96 \\
\hline 42 & III & Perform electronic transfer of accounting data & 3,913 & 1,002 & 25,60 \\
\hline 42 & VII & Social adaptability & 3,913 & 0,905 & 23,12 \\
\hline 46 & VI & $\begin{array}{l}\text { Present and defend points of view and the outcomes of } \\
\text { their own work, in writing, to colleagues, clients, and } \\
\text { superiors }\end{array}$ & 3,91 & 0,819 & 20,94 \\
\hline 47 & $\mathrm{~V}$ & The ability to use various information & 3,9 & 1,007 & 25,81 \\
\hline 48 & I & Track inventory analysis & 3,888 & 0,894 & 22,99 \\
\hline 49 & I & Strategic management & 3,888 & 0,894 & 22,99 \\
\hline 50 & I & Critical reading & 3,888 & 0,851 & 21,88 \\
\hline 51 & VI & Adapt to situation of changes & 3,88 & 0,769 & 19,81 \\
\hline 52 & VII & Prepare payroll & 3,876 & 0,98 & 25,26 \\
\hline 53 & I & Ability to stimulate and to facilitate & 3,851 & 0,979 & 25,25 \\
\hline 54 & VI & Sense of personal identity & 3,85 & 0,853 & 22,15 \\
\hline 55 & VII & Solve unstructured problems & 3,814 & 0,86 & 22,33 \\
\hline 56 & $\mathrm{~V}$ & Sense of humor & 3,802 & 0,963 & 25,24 \\
\hline
\end{tabular}




\begin{tabular}{llllll}
\hline 57 & VII & Computer Security skill & 3,802 & 0,88 & 23,14 \\
58 & III & Leadership & 3,790 & 1,029 & 27,06 \\
59 & VI & The effective use of visual aids in presentations & 3,775 & 0,876 & 23,11 \\
60 & VI & Analysis capacity and logical thinking & 3,765 & 0,927 & 24,55 \\
61 & V & Find effective ways to solve problems & 3,765 & 0,978 & 25,98 \\
62 & V & Pressure resistance & 3,76 & 0,972 & 25,82 \\
63 & VII & Optimism & 3,74 & 0,919 & 24,4 \\
64 & VII & The effective use of Electronic Data Interchange procedure & 3,740 & 0,98 & 26,20 \\
65 & III & Actuarial and risk assessment & 3,679 & 0,802 & 21,44 \\
66 & I & Analyze business performance & 3,65 & 0,985 & 26,77 \\
67 & I & Mastering Good Governance series & 3,592 & 0,937 & 25,67 \\
68 & II & Updating control procedures & 3,580 & 0,997 & 27,75 \\
69 & I & Empathy & 3,543 & 1,059 & 29,58 \\
70 & VII & Develop business plans & 3,518 & 0,846 & 23,87 \\
71 & II & Participate in planning & 3,481 & 1,026 & 29,16 \\
72 & II & Ethical Awareness & 3,382 & 1,073 & 30,82 \\
73 & VII & Organize and manage human resources & 3,333 & 0,936 & 27,69 \\
74 & II & The use of quantitative methods, and statistics & 3,283 & 1,204 & 36,12 \\
75 & II & Investment Analysis and Portfolio Management & 3,222 & 1,051 & 32,01 \\
76 & II & Advertising and promotion & 3,012 & 0,974 & 30,23 \\
77 & II & Practice sports & 2,94 & 1,318 & 43,76 \\
78 & IV & Ability to develop effective learning methods & 2,93 & 1,076 & 36,62 \\
\hline
\end{tabular}

Note: (I) Technical skills (accounting, financial and tax), (II) Management skills, (III) Information Technology Skills, (IV) Physical qualities, (V) Intellectual skills, (VI) Interpersonal skills and (VII) personal skills.

After conducting tests for individual items, we will try to make Skills analysis grouped by factors (see Table 5). In this context, we can notice that different categories of skills received important overall mean scores and close in term of value. This shows that students recognize the importance of development of these different skills. On the other hand, we note the dominance of technical skills base (mean score of 4.086). Even though, students recognize the importance of generic skills, they stress the importance of functional and technical abilities to succeed in their careers. In addition, Table 5 shows that the Cronbach's alpha was satisfactory (between 0.736 and 0.901 ) which demonstrates that the items share a common understanding and validate the reliability and the internal consistency of our measure.

Table 6. Analysis of cross-asset class skills: student ranking

\begin{tabular}{llcc}
\hline & Skills categories & Mean score & Cronbach's alpha \\
\hline I & Technical skills & $\mathbf{4 , 0 8 6}$ & 0,895 \\
II & Management skills & 3,349 & 0,736 \\
III & Information Technology Skills & 3,848 & 0,801 \\
IV & Physical qualities & 3,728 & 0,739 \\
V & Intellectual skills & 3,935 & 0,870 \\
VI & Interpersonal skills & 4,028 & 0,901 \\
VII & Personal skills & 3,903 & 0,879 \\
\hline
\end{tabular}




\subsection{Further Analysis: Difference between Employers' Expectations and Students' Perceptions}

In this section, we use the t-test to verify if there is a significant difference between students' perceptions and employers' expectations of employment skills and characteristics. The results shown in Table 6 indicate that even though there are similarities between student perceptions and employers' expectations, differences remain. In fact, both groups have recognized the importance of different skills categories; however, the ranking given by professionals and students for each skill factor was different. Moreover, the $t$-test shows significant differences in the following categories: technical skills, physical qualities, intellectual skills and personal skills. Moreover, it seems that students tend to perceive technical skills as more important than do employers. In addition, separate analysis of different all over mean scores reveals more specific between students' perceptions and employers' expectations. For instance, a critical gap found in our study was for "Ethical awareness" and "pressure resistance". Interestingly, employers ranked these skills highest in importance (Ranking Second out 78). However, students ranked ethics substantially lower in importance (ranking 72 out 78).

Other important gaps were found in the interpersonal and personal skills: teamwork, leadership and command sense, self-training, the ability to develop effective learning methods). It received a mean importance score of 4.323 among employers (ranking six out of 34) while the mean score for students was only 3.911 (ranking eighteenth). This finding also suggests that students may not realize how much employers value being rigorous and self motivated. In sum, we find that gaps exist between employer expectations of employment skills and characteristics, and student perceptions of those expectations. The gaps appear to arise from a lack of understand in terms of new skills expected for future accountants.

Table 7. The gap between employers' expectations and students' perceptions

\begin{tabular}{llcc}
\hline Skills categories & \multicolumn{2}{l}{ Mean score: students ranking Mean score: employers ranking } & Absolute difference \\
\hline Technical skills & 4,086 & 3,71 & $\mathbf{0 , 3 7 5 8 * * *}$ \\
Management skills & 3,349 & 3,31 & 0,034 \\
IT skills & 3,848 & 3,93 & 0,068 \\
Physical qualities & 3,728 & 3,92 & $\mathbf{0 , 1 9 3} * *$ \\
Intellectual skills & 3,935 & 4,14 & $\mathbf{0 , 2 0 5 * *}$ \\
Interpersonal skills & 4,028 & 4,11 & 0,0870 \\
Personal skills & 3,903 & 4,14 & $\mathbf{0 , 2 3 3}$ *** \\
\hline
\end{tabular}

***: significant at $1 \% ; *$ : significant at $5 \%$.

\section{Summary and Future Directions}

This article aimed to analyze the students' perceptions about the skills set required, and tried to bring them closer to employers' expectations in the Tunisian case. To achieve this goal, a sample of accounting students and professionals' accountants was invited to participate in the study. A four-page questionnaire was developed that was brief and free of specialized jargon. Seven factors were of interest in this study 1) Technical skills, 2) Management skills, 3) IT skills, 4) Physical qualities, 5) Intellectual skills, 6) Interpersonal skills and 7) Personal skills. In the first section of the survey, respondents were asked to "indicate how important it is for prospective employees to have the following skills.

The results of our study show that professional accountants admit that accounting graduates must possess a wide range of technical and generic skills in order to succeed their careers within the profession. This finding confirms the results of several previous researches (Albrecht and Sack, 2000; Gabric and McFadden, 2001; Kavanagh and Drenan, 2008). The results revealed also that employers emphasized the need for graduates to develop generic skills related to ethical awareness, communication, critical analysis and teamwork. According to students' perceptions, it seems that they tend to believe more in basic technical skills compared to other categories of skills. In fact, through the scores assigned to items, students report that technical skills allow the accounting graduate to pursue a successful career. However, they do not deny the importance of several generic skills.

Moreover, further analysis, based on the comparison of different mean score, reveals the existence of a gap between the students' perceptions and employers' expectations. While the only significant gap the most critical gaps in our study was among the technical skills factor, separate analysis of items revealed several differences 
between the responses of these two respondents groups. Thus, we find that in accordance with the Jones and Sin (2003) model, employers are seeking a diverse range of skills and attributes in new accounting graduates such as life experience, communication and teamwork.

However, students value technical skills higher than generic skills. This difference in perceptions may be the result of a lack of communication between students and professionals. Our results may explain in part why, in Tunisian university accounting graduates are having a difficulty at entry level. In summary, Tunisian employers are expecting graduates to be far more 'job ready' (Kavangh and Drenan, 2008) than is actually the case which results in gaps between students' perceptions and employers' expectations. We believe that this phenomenon, which tends to devalue the potential of students, is the result of a lack of openness of the Tunisian university on its professional environment. We propose in this context, to multiply the channels of exchange between the two "worlds" by introducing a new culture that minimizes this obsessive relentlessness which drives the majority of students to run only behind good marks. We believe that universities have to develop coherent policies and frameworks to promote cognitive intelligence, social, vocational and personal development. This could be achieved by the establishment of career centers and alumni associations... etc. Without a doubt, the skills debate will continue to rage. Future researches should include more studies on the perceptions of academics and graduates already employed in audit firms.

\section{References}

Accounting Education Change Commission. (1990). Objectives of education for accountants: position statement number one. Issues in Accounting Education, 5, 307-312.

ACNielsen Research Services. (2000). Employer Satisfaction with Graduate Skills: Research Report. Evaluations and Investigations Program Higher Education Division, DETYA.

Albrecht, W., \& Sack, R. (2000). Accounting Education charting the race-through a perilous future. Accounting Education Series, 16. Sarasota, FL: American Accounting Association.

Ameen, E., Jackson, C., \& Malgwi, C. (2010). Student perceptions of oral communication in the accounting profession Requirements. Global Perspectives on Accounting Education, 7, 31-49.

American Institute of Certified Public Accountants (AICPA). (1999). Core competency framework for entry into the accounting profession. New York: AICPA.

Arquero, J., Anes, J. A. D., Hassall, T., \& Joyce, J. (2001). Vocational skills in the accounting professional profile: The Chartered Institute of Management Accountants (CIMA) Employers opinion. Accounting Education: An International Journal, 10(3), 299-313. http://dx.doi.org/10.1080/09639280210122339

Baker, W. M., \& McGregor, C. C. (2000). Empirically Assessing the importance of characteristics of accounting students. Journal of Education for Business, 75(3), 49-157. http://dx.doi.org/10.1080/08832320009599006

Bescos, P. L. (2002). Current issues and future skills of the members of the public-finance management. Financial Control Strategy, 5, 5-28.

Birkett, W. P. (1993). Competency Based Standards for Professional Accountants in Australia and New Zealand. Institute of Chartered Accountants in Australia and the New Zealand Society of Accountants, Sydney (NSW).

Birrell, B. (2006). The Changing Face of the Accounting Profession in Australia. CPA Australia, Melbourne.

Borzi, G., \& Mills, T. H. (2001). Communication apprehension in upper level accounting students: An assessment of skill development. Journal of Education for Business, 76(4), 193-198. http://dx.doi.org/10.1080/08832320109601310

Bowden, J., Hart, G., King, B., Trigwell, K., \& Watts, O. (2000). Generic Capabilities of ATN University Graduates. Canberra: Australian Government Department of Education, Training and Youth Affairs.

Bui, B., \& Porter, B. (2010). The Expectation-Performance Gap in Accounting Education: An Exploratory Study. Accounting Education: An International Journal, 19(1-2), 23-50. http://dx.doi.org/10.1080/09639280902875556

Chaker, M. N., \& Abdullah, T. A. T. (2012). What Accountancy Skills Are Acquired at College? International Journal of Business and Social Science, 2(18). Retrieved from http://www.ijbssnet.com/journals/Vol_2_No_18_October_2011/24.pdf

Cronbach, L. J. (1951). Coefficient alpha and the internal structure of tests. Psychometrika, 16, 297-334. http://dx.doi.org/10.1007/BF02310555 
Daff, L., De Lange, P., \& Jackling, B. (2012). A Comparison of Generic Skills and Emotional Intelligence in Accounting Education. Issues in Accounting Education, 27(3), 627-645. http://dx.doi.org/10.2308/iace-50145

Daly, J. A., \& McCroskey, J. C. (1975). Occupational Desirability and Choice as a Function of Communication Apprehension. Journal of Counseling Psychology, 22(4), 309-313. http://dx.doi.org/10.1037/h0076748

De Lange, P., Jackeling, B., \& Gut, A. (2006). Accounting Graduates' perceptions of skills emphasis in Australian undergraduate accounting courses: an investigation from two Victorian universities. Accounting and Finance, 46, 365-386. http://dx.doi.org/10.1111/j.1467-629X.2006.00173.x

DiGabriele, J. A. (2008). An empirical investigation of the Relevant Skills of Forensic Accountants. Journal of Education for Business, 83(6), 331-338. http://dx.doi.org/10.3200/JOEB.83.6.331-338

Evrard, Y., Pras, B., \& Roux, E. (1993). Market Studies and Research in Marketing. Nathan, Paris.

Francisco, B., \& Kelly, A. (2002). Beyond Albrecht and Sack: A comparison of accounting professionals and college students.

Gabric, D., \& McFadden, K. (2001). Student perceptions and use of desirable entry-level operations management skills. Mid-American Journal of Business, 16, 51-59. http://dx.doi.org/10.1108/19355181200100005

Gammie, B., Gammie, E., \& Cargill, E. (2002). Personal skills development in the accounting curriculum. Accounting Education: An International Journal, 11(1), 63-78. http://dx.doi.org/10.1080/09639280210153272

Gati, I. (1998). Using career-related aspects to elicit preferences and characterize occupations for a better person-environment fit. Journal of Vocational Behaviour, 52(3), 343-356. http://dx.doi.org/10.1006/jvbe.1997.1623

Goleman, D. (1999). Emotional Intelligence: cultivate his emotions to flourish in his work. Paris, Editions Robert Laffont, p. 384.

Hassall, T., Joyce, J., Arquero Montano, J. L. A., \& Donkeys, J. A. D. (2005). Priorities for the development of vocational skills in management accountants: a European perspective. Accounting Forum, 29, 379-394. http://dx.doi.org/10.1016/j.accfor.2005.03.002

Hosmane, B., Maurath, C., \& Manski, R. (2000). Quality of life: Statistical validation and analysis an example from a clinicaltrial. In C. R. Rao and P. K. Sen. (Eds.), Handbook of Statistics: Bio-Environmental and Public Health Statistics, 18, 871-891.

Howieson, B. (2003). Accounting practice in the new millennium: is accounting education ready to Meet the Challenge? The British Accounting Review, 35, 69-103. http://dx.doi.org/10.1016/S0890-8389(03)00004-0

Hunt, S. C., \& Falgiani Intrieri, R. C. (2004). The Nature and Origins of Students 'Perceptions of Accountants'. Journal of Education for Business, 79(3), 142-148. http://dx.doi.org/10.3200/JOEB.79.3.142-148

Hunton, J. E. (2002). Blending Information and Communication Technology with Accounting Research. Accounting Horizons, 16(1), 56-67. http://dx.doi.org/10.2308/acch.2002.16.1.55

Institute of Chartered Accountants of England and Wales (ICAEW), Education and Training Committee. (1996). Added Value Professionals: Chartered Accountants in England and Wales 2005. London: ICAEW.

International Federation of Accountants (IFAC). (2002). International Education Standard on Professional Skills and General Education. IFAC, New York.

Jackling, B., \& De Lange, P. (2009). Accounting Graduates Do 'skills Meet the expectations of Employers? A matter of convergence or divergence. Accounting Education, 18, 369-385. http://dx.doi.org/10.1080/09639280902719341

Johnson, L. M., \& Johnson, V. E. (1995). Help wanted - accountant: what the classifieds say about Employers' $\begin{array}{lllll}\text { expectations. Journal of Education for } & \text { Business, } & 70, & \text { 130-134. }\end{array}$ http://dx.doi.org/10.1080/08832323.1995.10117738

Jones, A., \& Sin, S. (2003). Generic Skills in Accounting, Competencies for Students and Graduates. Prentice Hall, Frenchs Forest, NSW.

Jones, G. E., \& Abraham, A. (2008). Preparing accountants for today's global business environment: The role of Emotional Intelligence in accounting education. 11th Annual International Conference of the American 
Society of Business and Behavioral Sciences 2008 Honolulu, Hawaii, September, pp. 25-27.

Jones, G. E., \& Abraham, A. (2009). The Value of Incorporating Emotional Intelligence Skills in the Education of Accounting Students. The Australasian Accounting Business \& Finance Journal, 3(2), 48-63.

Kavanagh, M. H., \& Drenan, L. (2008). What skills and attributes Does year accounting graduate need? Evidence from student perceptions and use expectations. Accounting and Finance, 48, 279-300. http://dx.doi.org/10.1111/j.1467-629X.2007.00245.x

Kavanagh, M., Hancock, P., Howieson, B., Kent, J., \& Tempone, I. (2009). Stakeholders' perspectives of the skills and attributes for accounting graduates. In 2009 Accounting \& Finance Association of Australia and New Zealand Conference (AFAANZ 2009), 5-7 July 2009, Adelaide, Australia. Retrieved from $\mathrm{http}: / / \mathrm{www} . a f a a n z . o r g /$ openconf $/ 2009 /$ modules/request.php?module $=$ oc_program\&action=view.php\&id=31

Kerlan, F. (2000). Guide for the GPEC, Edition of organization. Group Eyrolles, 2000.

Kim, T. S., Ghosh, B. C., \& Meng, L. A. (1993). Selection criteria: perception gap Between Employers and accounting Graduates. Accountant Singapore, 9, 32-33.

Lee, D. W., \& Blaszczynski, C. (1999). Perspectives of "Fortune 500" executives on the competency Requirements for Graduates accounting. Journal of Education for Business, 75, 104-108. http://dx.doi.org/10.1080/08832329909598999

Leveson, L. (2000). Disparities in perceptions of generic skills: academics and Employers. Industry and Higher Education, 14, 157-164. http://dx.doi.org/10.5367/000000000101295002

Lin, Z. J., Xiong, X., \& Liu, M. (2005). Knowledge base and skill development in accounting education: Evidence from China. Journal of Accounting Education, 23(3), 149-169. http://dx.doi.org/10.1016/j.jaccedu.2005.06.003

Mathews, M. R., Jackson, M., \& Brown, P. (1990). Accounting in Higher Education: Report of the Review of the Accounting Discipline in Higher Education, 1. Australian Government, Canberra, ACT.

Mohamed, E. K., \& Lashine, S. H. (2003). Accounting knowledge and skills and the challenges of a global business environment. Managerial Finance, 29, 3-16. http://dx.doi.org/10.1108/03074350310768319

Morgan, G. J. (1997). Communication skills required by accounting Graduates: practitioner and academic perceptions. Accounting Education: An International Journal, 6, 93-107. http://dx.doi.org/10.1080/096392897331514

Novin, A. M., Pearson, M. A., \& Senge, S. V. (1990). Improving the curriculum for aspiring management accountants: The practitioner's point of view. Journal of Accounting Education, 8, 207-224. http://dx.doi.org/10.1016/0748-5751(90)90003-P

Rebele, J. E. (1985). An examination of accounting Students' perceptions of the importance of communication skills in public accounting. Issues in Accounting Education, 3, 41-50.

Siegel, G. (2000). The image of corporate accountants. Strategic Finance, 82(2), 71.

Siegel, G., \& Sorensen, J. E. (1999). Counting more, counting less. Transformation in the management accounting profession, Institute of Managing Accountants, Montvale, NJ.

Simons, K., Higgins, M., \& Lowe, D. (1995). A profile of communication apprehension in accounting majors: implications for teaching and curriculum revision. Journal of Accounting Education, 13(2), 159-176. http://dx.doi.org/10.1016/0748-5751(95)00001-3

Usoff, C., \& Feldmann, D. (1998). Accounting Students' perceptions of important skills for career success. Journal of Education for Business, 73, 215-220. http://dx.doi.org/10.1080/08832329809601633

Wells, P., Gebric, P., Kranenburg, I., \& Bygrave, J. (2009). Professional Skills and Capabilities of Accounting Graduates: The New Zealand Expectation Gap? Accounting Education: An International Journal, 18(4-5), 403-420. http://www.tandfonline.com/doi/abs/10.1080/09639280902719390

Yaich, A. (2005). Behavioral Accounting Intelligence. Sfax, Raouf Yaich Ed.

Zaid, O. A., \& Abraham, A. (1994). Communication skills in accounting education: perceptions of academics, Employers and graduate accountants. Accounting Education: An International Journal, 3(3), 205-221. http://dx.doi.org/10.1080/09639289400000020

Zikmund, W. G. (2000). Business Research Methods (6th ed.). Orlando, US: Dryden Press 2000. 


\section{Notes}

Note 1. A survey of the INS (National Statistics Institute) which dates from Tunisia in November 2011. This survey is visible on the link (document in Arabic): http://www.leaders.com.tn/uploads/FCK_files/file/Presentation_Enq_Emploi_2011_VF09.ppsx

Note 2. International Education Standards or international standards of education produced by IFAC (International Federation of Accoutants).

Note 3. Ministry of Manpower and Income Security, PSC. Text taken from "Report of the respondents' recognition of professional skills, Government of Quebec, in January 1988.

Note 4. Especially in the U.S., Australia, New Zealand and even the United Kingdom (AECC, 1990; AICPA, 1990; Mathews \& al., 1990; ASCPA, 1992; ICAEW, 1996).

Note 5. In this context, Jackling and De Lange (2009) reported that the Association of Chartered Accountants of Australia, will require universities to demonstrate how they have incorporated generic skills (32 in number, initially set by international standards of education accounting) for professional accreditation of its members belonging to these universities.

Note 6. These tests are based on interviews that we conducted with three professional accountants (two charted accountants and a certified public accountant) and three students from the third year license applied in accounting.

Note 7. Certified public accountants are members of the Institute of Certified Public Accountants of Tunisia (founded in 1982).

Note 8. The Chartered Accountants are members of the Society of Accountants of Tunisia (established since 2002).

Note 9. According to Evrard et al. (1993, p. 282), the value of this coefficient is acceptable if it is between 0.6 and 0.8 , for an exploratory study, whereas for a confirmatory study, the authors advocate a value greater than 0.8 . 